
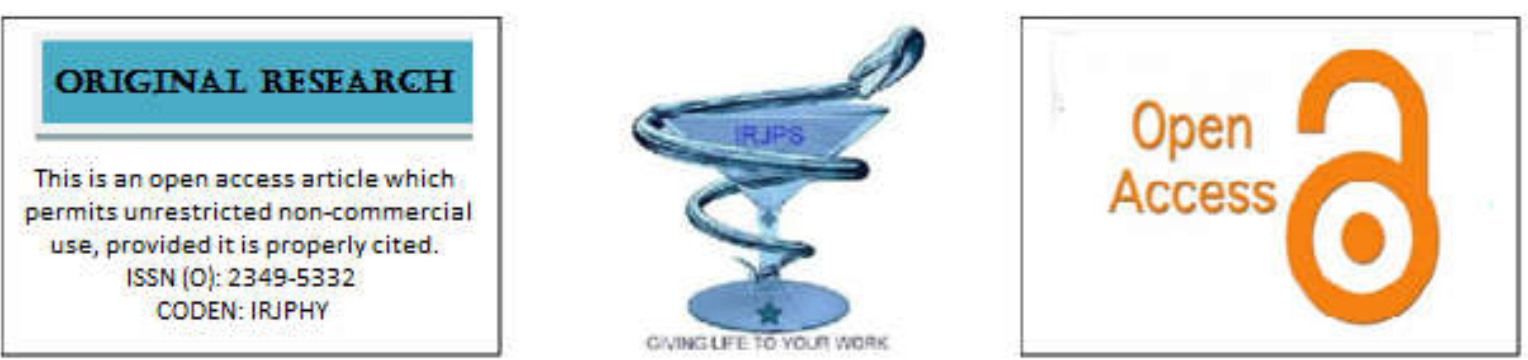

\title{
PREVALENCE OF CASES OF APPENDICITIS AMONG PATIENTS VISITING EMERGENCY DEPARTMENT AT JORDANIAN ROYAL MEDICAL SERVICES HOSPITALS, JORDAN
}

\author{
Ahmad Abedlaqader Aldhoun, Abedalbaset Talal Alzoubi, Zuhier Ali Ikhwayleh, Issam Fahmi Othman \\ Alrbeihat, Ibrahim Khalilabu Hussein, Ashraf Mohammad Sh. A.Odeh, Abdullah Anwar Ibrahim Abu Kaff \\ *Royal Medical Services, Jordan
}

Submitted on: 06.10.2020;

Revised on: 08.10.2020;

Accepted on: 09.10.2020

\begin{abstract}
In the emergency department, acute abdominal pain including acute appendicitis is more likely to be encountered. The main objectives of the present study were to identify the frequency of appendicitis and related variables such as gender, age, and month with the occurrence of appendicitis. Study methods included the conduction of retrospective study design. Study sample included 139 participants who visited emergency department at King Talal Hospital, Royal Medical Services, Jordan. Study variables included age, gender, month, and the level of white blood cells. Study findings showed that males were more likely to develop appendicitis compared with females, the mean age of participants was about 25 years. The mean level of White blood cells was $13673.65 \pm 5439.61 / \mathrm{ml}^{3}$. Winter season witnessed the most frequent cases of appendicitis. There were significant variations in the level of white blood cells between males and females, in which females had higher levels of white blood cells compared to males ( $\mathrm{p}=0.003$ ). Taken together, acute appendicitis is more encountered among males, and in Winter season, particularly, January. It seems that females exhibit more pathologic events compared with males.
\end{abstract}

KEYWORDS: Acute appendicitis, abdominal pain, WBC, age, gender, month

Corresponding Author: A. T. Alzoubi E-mail: Dr.abedalbaset@yahoo.com Mobile: +962 797064078
Indian Research Journal of Pharmacy and Science; 26(2020)2386-2390; Journal Home Page: https://www.irjps.in DOI: 10.21276/irjps.2020.7.3.6 


\section{INTRODUCTION:}

A ruptured appendix is one of the most well-known careful crises in the United States (1). Nonetheless, the analysis of an infected appendix is missed in $3.8 \%$ to $15.0 \%$ of youngsters and in $5.9 \%$ to $23.5 \%$ of grown-ups during crisis division (ED) visits (2-4). Appendicitis is the second most encountered condition among pediatric patients and the third most basic condition referred to in grown-up negligence protection claims (5).

The emergency department (ED) is a setting in which it is the first line to receive different cases, and accordingly, there is a risk to have diagnostic errors $(6,7)$.It has been estimated that acute abdominal pain is responsible for up to $10 \%$ of all entries to ED (8, $9)$. Acute appendicitis is considered one of the most frequent reasons of lower abdominal pain forcing patients to access the $\operatorname{ED}(10,11)$.

The level of white blood cell is considered to assess the preoperative scoring system for the differentiation of perforation risk among pediatric patients with acute abdominal pain. This system depends on the duration of symptoms ( $>1$ day), fever ( $>38.0 \mathrm{C}$ ), and WBC absolute count (> 13,000/mm3) (12).

\section{Study objectives:}

the main objectives of this study were to identify the frequency of appendicitis and related variables such as gender, age, and month with the occurrence of appendicitis.

\section{METHODS AND SUBJECTS:}

\section{Study design and setting:}

A retrospective design was conducted in this study to collect data from study participantswho visited emergency departmentat King Talal Hospital, Royal Medical Services, Jordan. Files in which patients have come with acute appendicitis were included in the study. Study variables included age, gender, month of visiting, and white blood cell count. Study sample included 139 patients who were subjected to appendicitis.

All data were entered excel spreading sheet. Data were analyzed using SPSS version 21. Data were presented as frequencies and percentages for categorical variables, means and standard deviations for linear variables. The relationships between variables were computed using independent $T$ test. Significance was considered at $\alpha \leq 0.05$.

\section{RESULTS:}

\section{General characteristics of participants}

As seen in table 1, the mean age of study participants was $24.70 \pm 14.2$ years. A total of $104(74.8 \%)$ of participants were males. The mean WBC was $13673.65 \pm 5439.61$ cells $/ \mathrm{ml}$. regarding the frequency of appendicitis, about $33 \%$ of cases were operated by January, $22.3 \%$ by February, about $16 \%$ by March, about $19 \%$ by April, about $4 \%$ by both May and June, and about $2 \%$ by July.

Table 1: General characteristics of participants

\begin{tabular}{|c|c|}
\hline Variable & Description \\
\hline Age $(M \pm S D)$ years & $24.70 \pm 14.2$ \\
\hline $\begin{array}{cc}\text { Gender }(\mathbf{N}, \%): \\
-\quad \text { Male } \\
-\quad \text { Female }\end{array}$ & $\begin{array}{c}104(74.8 \%) \\
35(25.2 \%)\end{array}$ \\
\hline $\mathrm{WBC}(\mathrm{M} \pm \mathrm{SD})$ cells $/ \mathrm{ml}^{3}$ & $13673.65 \pm 5439.61$ \\
\hline $\begin{array}{rc}\text { Frequency of appendicitis per month }(\mathbf{N}, \%): \\
-\quad \text { January } \\
- & \text { February } \\
- & \text { March } \\
- & \text { April } \\
- & \text { May } \\
- & \text { June } \\
- & \text { July }\end{array}$ & $\begin{array}{c}46(33.1 \%) \\
31(22.3 \%) \\
22(15.8 \%) \\
27(19.4 \%) \\
5(3.6 \%) \\
5(3.6 \%) \\
3(2.2 \%)\end{array}$ \\
\hline
\end{tabular}


The frequency of appendix variables by gender

As shown in table 2, the mean age for males and females were close to each other $(24.78 \pm 11.62$ for males, and $24.46 \pm 20.23$ for females). The mean of WBCs for males $(13333.64 \pm 5176.65)$ was less than that of females $(14683.94 \pm 6124.74)$.

Table 2: The frequency of appendix variables by gender

\begin{tabular}{|c|c|}
\hline Variable & Description \\
\hline Age (M \pm SD) years: & $24.78 \pm 11.62$ \\
Males & $24.46 \pm 20.23$ \\
Females & \\
& \\
\hline WBC $(M \pm$ SD) cells $/ \mathrm{ml}:$ & $13333.64 \pm 5176.65$ \\
$-\quad$ Males & $14683.94 \pm 6124.74$ \\
\hline
\end{tabular}

As shown in figure 1 , males were more frequent to

subject for appendicitis in all studied months except for June.

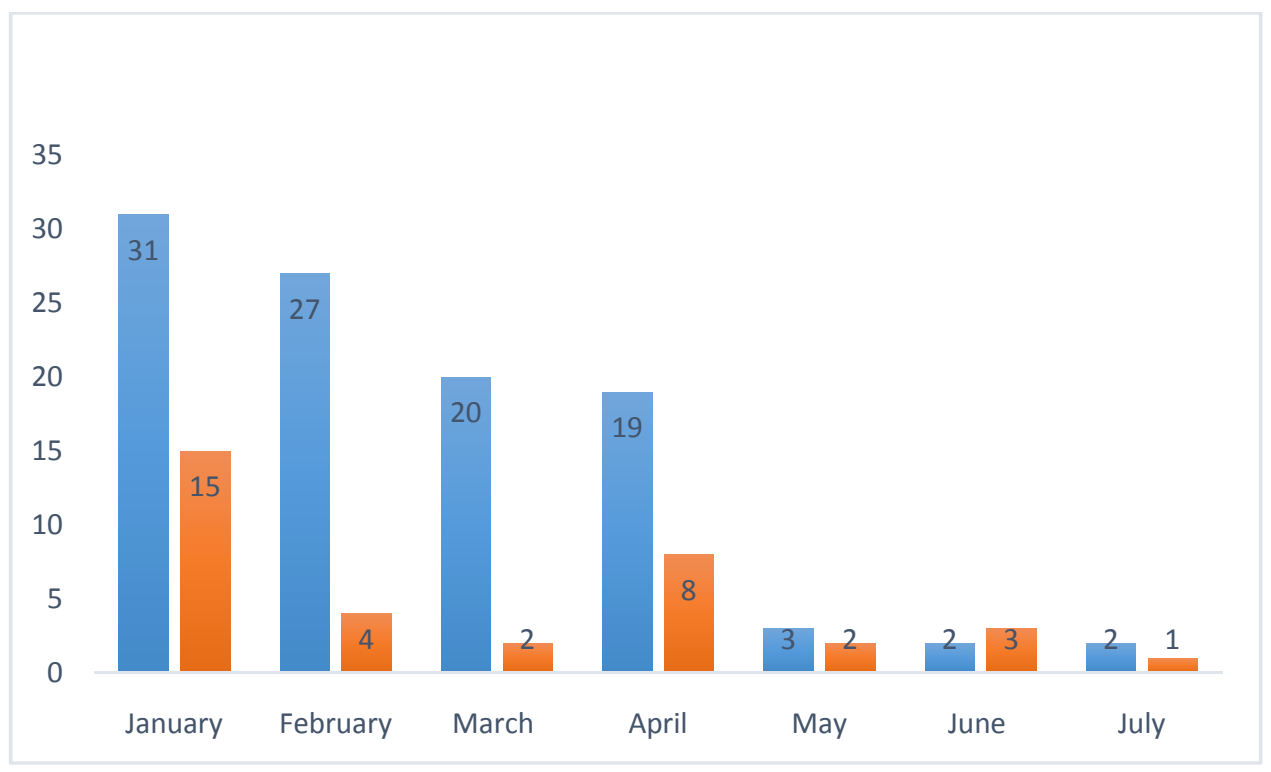

Figure 1: The frequency of appendicitis by month (blue for males, orange for females)

\section{The effects of gender on study variables}

we conducted $\mathrm{T}$ test to investigate the impact of gender on both age and WBC. As shown in table
3 , gender had no effect on age $(p=0.711)$. On the other hand, gender had a significant effect on WBC $(\mathrm{p}=0.003)$. 
Table 3: The effect of gender on study variables

\begin{tabular}{|c|c|c|c|c|c|}
\hline \multicolumn{2}{|c|}{} & Mean & N & Std. Deviation & P value \\
\hline \multirow{2}{*}{ Pair 1 } & Age_male & 25.9143 & 35 & 9.37259 & 0.711 \\
\cline { 2 - 5 } & Age_female & $\mathbf{2 4 . 4 5 7 1}$ & 35 & $\mathbf{2 0 . 2 3 1 5 2}$ & \\
\hline \multirow{2}{*}{ Pair 2 } & WBC_male & $\mathbf{1 0 4 0 6 . 5 4 0 0}$ & 35 & $\mathbf{4 8 7 0 . 3 4 2 3 9}$ & \multirow{2}{*}{0.003} \\
\cline { 2 - 5 } & WBC__female & $\mathbf{1 4 6 8 3 . 9 4 2 9}$ & 35 & 6124.73658 & \\
\hline
\end{tabular}

\section{DISCUSSION:}

The present study showed that the mean age of study participants with appendicitis was about 25 years. Age seems to be a varying agent in various studies. Other studies found the mean age of study participants who were subjected for appendectomy was 39 years (13). However, age is expected to vary among studies due several factors such as study size, and culture.

The present study showed that males were more likely to have appendicitis compared with their counterparts of females. This finding is consistent with previous studies (14), in which authors analyzed large data of patients with appendicitis.

The level of WBCs in this study indicated that inflammation was a prominent feature of appendicitis and this confirmed other studies $(12,15,16)$. The level of WBC may also indicate to the pattern of behavior of appendicitis in which antibiotic treatment could be beneficial or not (15).

The results of the present study indicated that appendicitis is more likely to develop in winter compared with other seasons. These findings do not agree with other studies in which Summer and Spring were the most frequently seasons for reporting appendicitis $(17,18)$. It seems the environmental factors play significant roles in these studies, while in our study, we think that in Winter, acute abdominal pain is more likely to develop which increase the likelihood of developing appendicitis.

The results of this study showed that females were more likely to develop higher levels of WBCs which reflects more inflammatory conditions compared with males. We have to take into consideration that some factors like hormonal factors may increase the inflammatory status in females (1).
CONCLUSION: The present study showed that acute appendicitis is more encountered among males, and in Winter season, particularly, January. It seems that females exhibit more pathologic events compared with males.

\section{REFERENCES:}

1. Prashant Mahajan, TanimaBasu, Chih-Wen Pai, Hardeep Singh, Nancy Petersen, M. Fernanda Bellolio, Samir K. Gadepalli, Neil S. Kamdar, MA. Factors Associated with Potentially Missed Diagnosis of Appendicitis in the Emergency Department. JAMA Network Open. 2020;3(3):e200612. doi:10.1001/jamanetworkopen.2020.0612.

2. Galai T, Beloosesky OZ, Scolnik D, Rimon A, Glatstein M. Misdiagnosis of acute appendicitis in children attending the emergency department: the experience of a large, tertiary care pediatric hospital. Eur J $\begin{array}{llll}\text { Pediatr Surg. 2017;27 } & \text { (2):138-141. }\end{array}$ doi:10.1055/s-0035-1570757.

3. Naiditch JA, Lautz TB, Daley S, Pierce MC, Reynolds M. The implications of missed opportunities to diagnose appendicitis in children. AcadEmerg Med. 2013;20(6):592596. doi:10.1111/acem.12144

4. Leung YK, Chan CP, Graham CA, Rainer TH. Acute appendicitis in adults: diagnostic accuracy of emergency doctors in a university hospital in Hong Kong. Emerg Med Australas. 2017;29(1):48-55. doi:10.1111/1742-6723.12738.

5. Brown TW, McCarthy ML, Kelen GD, Levy F. An epidemiologic study of closed emergency department malpractice claims in 
a national database of physician malpractice insurers. AcadEmerg Med. 2010;17(5):553560. doi:10.1111/j.1553-2712.2010.00729.x

6. Medford-Davis LN, Singh H, Mahajan P. Diagnostic decision-making in the emergency department. PediatrClin North Am. 2018;65(6):1097-1105. doi:10.1016/j.pcl.2018.07.003

7. Mahajan P, Mollen C, Alpern ER, et al. An operational framework to study diagnostic errors in emergency departments: findings from a consensus panel [published online November 25, 2019].J Patient Saf. doi:10.1097/ PTS.0000000000000624.

8. Di Saverio, S., Podda, M., De Simone, B. et al. Diagnosis and treatment of acute appendicitis: 2020 update of the WSES Jerusalem guidelines. World J EmergSurg 15, $27 \quad$ (2020). https://doi.org/10.1186/s13017-020-00306$\underline{3}$.

9. Cervellin G, Mora R, Ticinesi A, et al. Epidemiology and outcomes of acute abdominal pain in a large urban Emergency Department: retrospective analysis of 5,340 cases. Ann Transl Med. 2016;4:362.

10. Ilves I. Seasonal variations of acute appendicitis and nonspecific abdominal pain in Finland. WJG. 2014;20:4037.

11. Viniol A, Keunecke C, Biroga $\mathrm{T}$, et al. Studies of the symptom abdominal pain--a systematic review and meta-analysis. Fam Pract. 2014;31:517-29.

12. Bonadio W, Shahid S, Vardi L, et al. A preoperative clinical scoring system to distinguish perforation risk with pediatric appendicitis. J Pediatric Surg. 2018;53:4415.
13. Renteria O, Shahid Z, Huerta S. Outcomes of appendectomy in elderly veteran patients. Surgery. 2018;164:460-5.

14. Faiz, Omar BSc(Hons), MBBS, FRCS, MS*; Clark, Jeremy BSc(Hons), MBBS, MSc, FRCS $^{\dagger}$; Brown, Tim MRCS ${ }^{*}$; Bottle, Alex $\mathrm{PhD}^{\ddagger}$; Antoniou, Anthony FRCS ${ }^{\S}$; Farrands, Paul BMedSci(Hons), BMBS, FRCS, DM ${ }^{\dagger}$; Darzi, AraFREng, KBE, FMedSci i; Aylin, Paul MBChb, FFPH ${ }^{\ddagger}$ Traditional and Laparoscopic Appendectomy in Adults: Outcomes in English NHS Hospitals Between 1996 and 2006, Annals of Surgery: November 2008 - Volume 248 - Issue 5 - p 800-806 doi: 10.1097/SLA.0b013e31818b770c.

15. Yu C-W, Juan L-I, Wu M-H, et al. Systematic review and meta-analysis of the diagnostic accuracy of procalcitonin, Creactive protein and white blood cell count for suspected acute appendicitis. Br J Surg. 2013;100:322-9.

16. Hansson J, Khorram-Manesh A, Alwindawe A, et al. A model to select patients who may benefit from antibiotic therapy as the first line treatment of acute appendicitis at high probability. J Gastrointest Surg. 2014;18:961-7.

17. Ahmed W, Akhtar MS, Khan S. Seasonal variation of acute appendicitis. Pak J Med Sci. 2018;34(3):564-567. doi:10.12669/pjms.343.14793.

18. Saps M, Blank C, Khan S, Seshadri R, Marshall B, Bass L, et al. Seasonal variation in the presentation of abdominal pain. $\mathrm{J}$ PediatrGastroenterolNutr. 2008;46:279284. doi:10.1097/mpg.0b013e3181559bd3. 